\title{
SNOW ACGUMULATION STUDiES ON THE THULE PENINSULA, GREENLAND
}

\author{
By Steven J. Mock \\ (U.S. Army Cold Regions Research and Engineering Laboratory, Hanover, New Hampshire \\ 03755, U.S.A.)
}

Abstract. Data from stake measurements, marker boards and pits along a $136 \mathrm{~km}$ trail crossing the Thule peninsula sector of the Greenland ice sheet have been used to determine both the regional and local distribution of snow accumulation. On a regional scale trend surfaces of mean annual accumulation can be adequately predicted from a model using distance from moisture source and elevation as independent parameters. A series of step- or wave-like features break the smooth profile of the ice sheet and cause profound changes in accumulation rates on a local scale. The accumulation pattern over these features can be predicted from surface slope and departure from regional elevation. Profiles of surface and subsurface topography indicate a direct relationship between subsurface hills and step-like features, but cannot be quantitatively accounted for by existing ice-flow theory. Detailed accumulation studies in conjunction with a program of spirit leveling in the vicinity of Camp Century has revealed the development a shallow valley-like feature. Within this feature accumulation rates have increased indicating that it is the result of flow phenomena.

Résumé. Études de l'accumulation sur la péninsule de Thulé, Groenland. Des données obtenues par observation de jalons, balises repères et puits placés le long d'une piste de $136 \mathrm{~km}$ traversant la région de la péninsule de Thulé sur l'indlandsis du Groenland ont été utilisées pour déterminer les distributions locales et régionales de l'accumulation. A l'échelle régionale, les tendances superficielles concernant l'accumulation annuelle moyenne peuvent être prévues de manière satisfaisante en utilisant un modèle faisant usage de la distance à la source d'humidité et de l'élévation en tant que paramètres indépendants. Une série d'irrégularités topographiques en forme de marches ou de vagues rompt le profil uniforme de l'indlandsis et cause de profonds changements des taux d'accumulation à l'échelle locale. La distribution des accumulations sur ces irrégularités peut être prévue en utilisant la pente des surfaces et les déviations à partir de l'élévation régionale. Les profils topographiques superficiels et sous-superficiels indiquent une relation directe entre les collines soussuperficielles et les irrégularités en forme de marches, mais ils ne peuvent pas être expliqués de manière quantitative par la présente théorie de l'écoulement de la glace. Des études détaillées de l'accumulation effectuées en relation avec un projet de nivellement au voisinage du camp "Century" ont révélé la formation d'une irrégularité en forme de vallée peu profonde. Au sein de cette irrégularité, les taux d'accumulation ont augmenté montrant qu'elle est causée par le phénomène d'écoulement.

Zusammenfassung. Schneeauftragsstudien auf der Thule-Halbinsel, Grönland. Ergebnisse von Pegelmessungen, Markierungsflächen und Schächten längs einer $136 \mathrm{~km}$ langen Piste über das grönländische Inlandeis auf der Thule-Halbinsel wurden zur Bestimmung der regionalen und lokalen Verteilung des Schneeauftrages herangezogen. Auf regionaler Ebene können Flächen gleicher mittlerer Jahresakkumulation hinreichend zuverlässig aus einem Modell vorausbestimmt werden, das den Abstand von der Feuchtigkeitsquelle und die Meereshöhe als unabhängige Parameter benutzt. Eine Reihe von stufen- oder wellenartigen Erscheinungen unterbrechen die glatte Oberfläche des Inlandeises und verursachen starke Wechsel des Schneeauftrags im lokalen Bereich. Die Akkumulationsverteilung über diesen Erscheinungen kann aus dem Oberflächengefälle und der Abweichung gegen die regionale Höhenlage vorhergesagt werden. Profile der Oberfläche und der Untergrundstopographie zeigen eine direkte Beziehung zwischen Erhebungen im Untergrund und stufenartigen Erscheinungen an, die jedoch quantitativ nicht aus der heutigen Theorie des Eisfliessens erklärt werden kann. Detaillierte Akkumulationsstudien in Verbindung mit einem geometrischen Nivellement in der Umgebung von Camp Century haben die Bildung einer seichten, talartigen Einsenkung aufgedeckt. Innerhalb dieser Einsenkung haben die Auftragsraten zugenommen, was auf ihre Entstehung als Fliesserscheinung hinweist.

\section{INTRODUCTION}

Since the construction of Camp Century by the U.S. Army in 1959 and r960, U.S. Army Cold Regions Research and Engineering Laboratory has used the facility as a site for research and engineering studies. A long term project to determine ice movement rates and particle paths from Camp Century to their point of discharge was initiated in $196 \mathrm{I}$. As part of this study, accumulation measurements, Io meter snow temperature measurements, ice thickness determinations and an extensive survey program have been undertaken. For previously published work relating to various aspects of this project see Mock ( 1963 ), Bailey and others (r964), Mock (r965), Waite (r965), Mock and Weeks (r966), and Clarke (r966). This report presents the results of accumulation studies carried out between 196 I and 1966 , with emphasis upon accumulation patterns, i.e. the spatial distribution of accumulation. A later report will concern itself with temporal variations of accumulation. 


\section{Area of Investigation}

The Thule peninsula is a westward projection of land, largely covered by the ice sheet and bounded by Inglefield Bugt on the north, Melville Bugt on the south, and Baffin Bay on the west (Fig. I). Camp Century is located at lat. $77^{\circ} \mathrm{II}^{\prime} \mathrm{N}$. and long. 6 $\mathrm{I}^{\circ} \mathrm{Io}^{\prime} \mathrm{W}$. near the crest line of the peninsula at an approximate elevation of I $885 \mathrm{~m}$. Extensive areas of ice-free land are exposed in the western and northern parts of the peninsula while scattered nunataks appear in the south. Small independent ice caps occur in the north-western part. In many respects, the lobe of the ice sheet covering the Thule peninsula can be visualized as the Greenland ice sheet in miniature, i.e. it has a generally linear shape with a distinct crest line, a mountain barrier to the south channeling flow into large outlet glaciers, and rolling uplands to the west where the ice sheet ends in broad ramps and cliffs. Figure I shows the Thule peninsula and routes followed by various investigators.

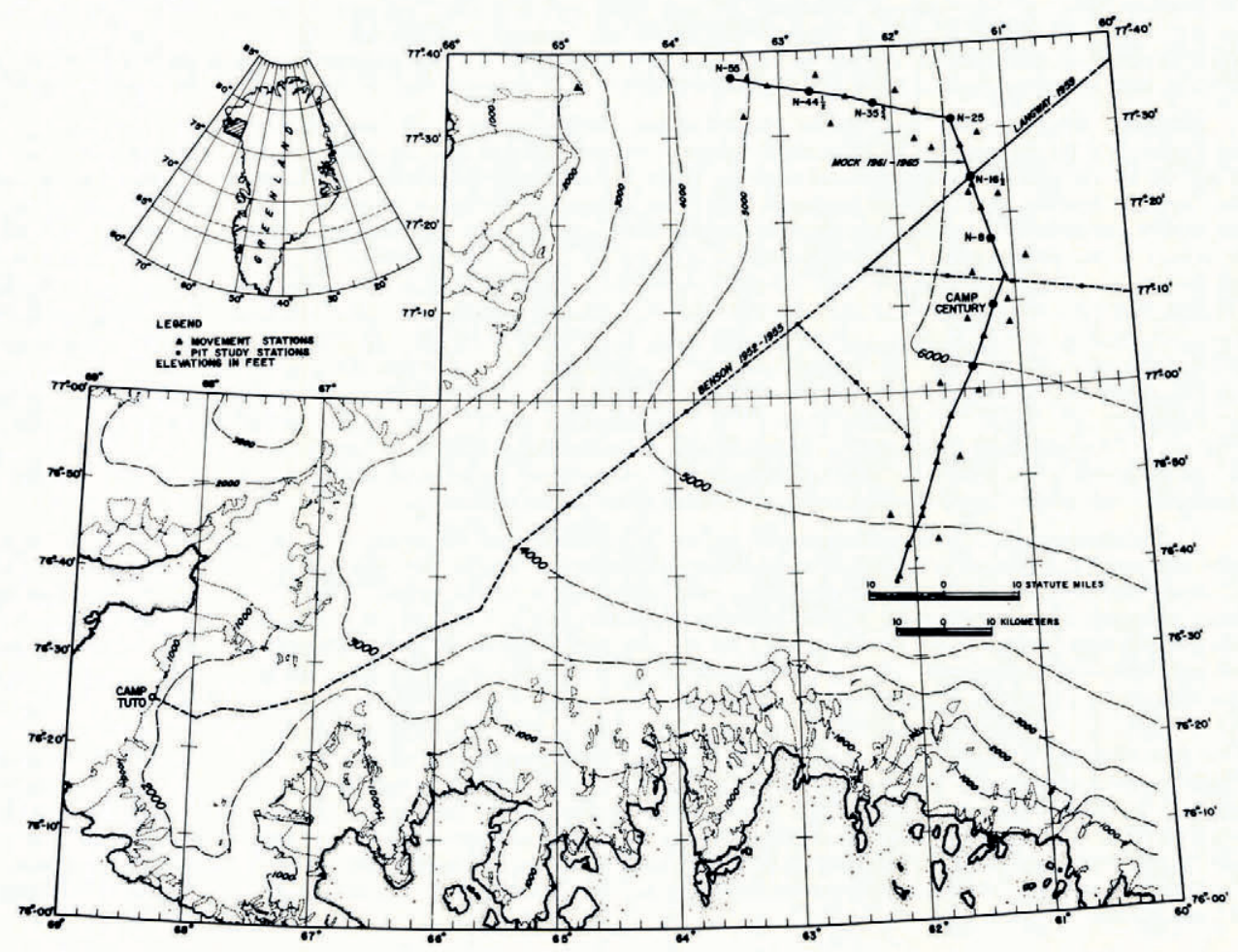

Fig. I. Location map of the Thule peninsula

\section{Previous Work}

North-west Greenland and the Thule peninsula have been the site of several glaciological investigations in recent years. Schytt (1955) and Griffiths (1960) studied the regimen and movement of the Thule ramp while Nobles ( 1960 ) carried out a similar program on the Nunatarssuaq ramp. Bull (1958) determined mean annual accumulation values from rammsonde measurements on a traverse from the east coast to the west coast. Goldthwait (1960) made an exhaustive study of an ice cliff on Nordisen near its junction with the main ice sheet. Bader (r955) studied the stratigraphy exposed in a $31 \mathrm{~m}$ deep pit at Site 2, $130 \mathrm{~km}$ east of Camp Century, and determined annual accumulation values for the period I9r9-54. Langway ( $196 \mathrm{r}$ ), in a series of pit studies showed empirical correlations of Io $\mathrm{m}$ 
snow temperatures, mean annual accumulation, and mean snow density with surface slopes and elevation. The most extensive investigations were made by Benson (1962) in a series of traverses during the period I952-55. Benson developed techniques for the correlation of stratigraphic features between pits and introduced the facies concept to the upper snow layers. His work included the correlation of environmental parameters, i.e. mean annual accumulation and temperature, with spatial position.

\section{Techniques and Measurements}

\section{Pit studies}

Standard snow-pit studies were made at I 3 to $18 \mathrm{~km}$ intervals along the trail. Locations of pit stations are shown in Figure I. Each pit study included stratigraphic delineation of annual units, a depth-density profile to a minimum of ro meters depth, measurement of Io meter snow temperatures, and a rammsonde profile to 4 meters.

\section{Stake and board measurements}

Snow accumulation measurements were made on stakes at $1.6 \mathrm{~km}$ (I mile) intervals along the trail south-west from Camp Century (south trail), for a distance of $48 \mathrm{~km}$. The stake line was established in I96 I and measured annually through i 965 . Marker boards were placed on the surface at $1.6 \mathrm{~km}$ ( 1 mile) intervals to provide dateable surfaces along the $88 \mathrm{~km}$ trail extending north-west and west from Camp Century (north trail). The boards were laid in I 962 and depths to them measured in 1964 and 1965 . Marker boards were also established as part of a spirit-level net surrounding Camp Century. A total of 33 boards were laid out in a rectangular area approximately $4.5 \mathrm{~km}$ by $6.5 \mathrm{~km}$. This array was initially established in I 963 and measurements were made in 1964 and 1966.

All stake and board measurements of snow accumulation were reduced to units of $\mathrm{g} / \mathrm{cm}^{2}$ of water by extrapolating from depth-density profiles at pit stations. Thus accumulation, in water-equivalent units, is available for the same three-year period for the entire $136 \mathrm{~km}$ of trail, and for an overlapping three-year period in the immediate environs of Camp Century.

\section{Elevations and leveling}

Elevations at movement stations were established by simultaneous reciprocal vertical angle measurements tied to coastal triangulation stations of the Danish Geodætisk Institut. Elevations between movement stations were determined by barometric altimetry. The level net surrounding Camp Century was established by spirit leveling in 1963 and was releveled in I964 and i 966 . Movement station $\mathrm{P}_{42-9}$ was used as the datum for each survey. Its elevation was assumed constant and all other elevations are relative to it.

\section{Ice thickness profiles}

Ice thickness was determined over the trail system in 1964 by radar and seismic methods. For discussions and results of radar measurements see Bailey and others ( I964), Waite (I966), and Rinker and Mock (1967). Seismic results have been presented by Clarke (1966). In addition to the above measurements, a radar traverse around the perimeter of the Camp Century level net was made using the U.S. Army Electronics Research and Development Laboratory's $35 \mathrm{MHz}$ radar sounder. Earlier seismic work within the Camp Century level net has been reported by Alford (Mock, 1965).

\section{Statistical analysis}

Multiple regression techniques were used to study areal trends of mean annual accumulation, as determined from pit studies and direct measurements. The treatment was essentially the same as used in earlier papers (Mock and Weeks, r966; Mock, r967) of studies of ro m snow temperature and accumulation distribution over the entire Greenland ice sheet. For 
details of the method see those papers or, for a complete treatment, Krumbein and Graybill ([1966]).

Briefly, the method is to establish a model for predicting mean annual accumulation at a point in terms of its spatial coordinates and by means of multiple linear regression using the least-squares method to derive a predictor equation satisfying certain pre-set statistical criteria. The resulting equations can be used directly or for the construction of trend surface maps.

\section{Results}

Table I summarizes the results of pit studies and direct measurements of accumulation. Figure 2 shows in graphical form mean annual accumulation from the stake and board measurements together with surface and subsurface profiles along the trails. Some important features of Figure 2 which will be discussed further are:

I. The general decrease in mean annual accumulation towards the interior.

2. The wide fluctuation in accumulation rates at adjacent stations, particularly from stations $\mathrm{S}-20$ to $\mathrm{S}-30$.

3. The association of subsurface with surface relief features and in turn with accumulation rates.

Throughout the following analysis the stake and board data rather than pit data have been used.

Table I. Data for Agcumulation Stations

\begin{tabular}{|c|c|c|c|c|c|c|c|c|c|}
\hline Station & $\begin{array}{c}\text { Elevation } \\
\mathrm{m}\end{array}$ & $\begin{array}{c}\text { Annual } \\
\text { accumulation } \\
\text { rate } \\
\mathrm{g} / \mathrm{cm}^{2} \text { year }\end{array}$ & $\begin{array}{l}\text { No. of } \\
\text { years }\end{array}$ & Method & Station & $\begin{array}{c}\text { Elevation } \\
\mathrm{m}\end{array}$ & $\begin{array}{c}\text { Annual } \\
\text { accumulation } \\
\text { rate } \\
\mathrm{g} / \mathrm{cm}^{2} \text { year }\end{array}$ & $\begin{array}{l}\text { No. of } \\
\text { years }\end{array}$ & Method \\
\hline $\mathrm{S}-30$ & 1524 & $81.8(54.8)$ & $3(5)$ & Stake (Pit) & N-I 6 & I 874 & 20.7 & 3 & Board \\
\hline S-27 & 1601 & $77 \cdot 3$ & 3 & Stake & N-I 6.5 & I 874 & 18.2 & 7 & Pit \\
\hline S-26 & I 622 & 63.0 & 3 & Stake & $N-17$ & 1872 & 22.3 & 3 & Board \\
\hline S-25 & I 636 & 74.0 & 3 & Stake & $N-18$ & 1868 & 21.8 & 3 & Board \\
\hline $\mathrm{S}-24$ & I 666 & $55 \cdot 5$ & 3 & Stake & N-19 & I 866 & 21.6 & 3 & Board \\
\hline $\mathrm{S}-23$ & 1658 & 72.2 & 3 & Stake & $\mathrm{N}-20$ & 1867 & 22.4 & 3 & Board \\
\hline $\mathrm{S}-22$ & 1701 & 46.0 & 3 & Stake & $\mathrm{N}-2 \mathrm{I}$ & 1871 & 21.6 & 3 & Board \\
\hline $\mathrm{S}-20$ & I 723 & $56.8\left(4^{6.8)}\right.$ & $3(7)$ & Stake (Pit) & $\mathrm{N}-22$ & 1870 & 20.2 & 3 & Board \\
\hline S-19 & $173^{\circ}$ & $5^{8.0}$ & 3 & Stake & $\mathrm{N}-23$ & I 867 & I9.8 & 3 & Board \\
\hline S-18 & I 747 & $47 \cdot 4$ & 3 & Stake & $\mathrm{N}-25$ & 1868 & I6.2 & 7 & Pit \\
\hline S-1 7 & I 757 & $53 \cdot 4$ & 3 & Stake & $\mathrm{N}-26$ & I 855 & 22.7 & 3 & Board \\
\hline S-16 & 1765 & $5^{1} \cdot 9$ & 3 & Stake & $\mathrm{N}-28$ & I 835 & 20.6 & 3 & Board \\
\hline S-I 5 & 1776 & $5^{\mathrm{I}} \cdot 2$ & 3 & Stake & $\mathrm{N}-30$ & 181 7 & 20.8 & 3 & Board \\
\hline S-1 4 & I 787 & $49 \cdot 3$ & 3 & Stake & $\mathrm{N}-32$ & I 787 & $2 \mathrm{I} \cdot \mathrm{I}$ & 3 & Board \\
\hline $\mathrm{S}-13$ & I 793 & $49 \cdot 0$ & 3 & Stake & $\mathrm{N}-34$ & $177^{\circ}$ & 21.7 & 3 & Board \\
\hline S-1 2 & 1802 & 43.8 & 3 & Stake & $N-35^{\frac{3}{4}}$ & 1760 & 18.2 & 7 & Pit \\
\hline S-1 1 & 1811 & 43.2 & 3 & Stake & $N-36$ & 1757 & 22.8 & 3 & Board \\
\hline S-10 & 1818 & $46.0\left(3^{6.5}\right)$ & $3(7)$ & Stake (Pit) & $\mathrm{N}-3^{8}$ & I 735 & $23 \cdot 3$ & 3 & Board \\
\hline S-9 & I 826 & $4^{1.8}$ & 3 & Stake & $\mathrm{N}-40$ & 1712 & 20.3 & 3 & Board \\
\hline S-8 & I 834 & $4^{1.2}$ & 3 & Stake & $N-41$ & I 695 & $25 . \mathrm{I}$ & 3 & Board \\
\hline S-7 & I 843 & 42.8 & 3 & Stake & $N-42$ & 1685 & $2 \overline{6} .0$ & 3 & Board \\
\hline S-6 & $185^{\circ}$ & $4^{1} \cdot 7$ & 3 & Stake & $\mathrm{N}-43$ & I 664 & $23 \cdot 3$ & 3 & Board \\
\hline S-5 & I 857 & 40.3 & 3 & Stake & $\mathrm{N}-44$ & I 655 & 25.2 & 3 & Board \\
\hline $\mathrm{S}-4$ & 1863 & 39.0 & 3 & Stake & $N-44.5$ & I 649 & 22.5 & 7 & Pit \\
\hline $\mathrm{S}-3$ & 1867 & 40.6 & 3 & Stake & $N-45$ & I 642 & 24.9 & 3 & Board \\
\hline N-5 & 1889 & $3^{2} \cdot 3$ & 3 & Board & $N-46$ & I 624 & 27.5 & 3 & Board \\
\hline$N-6$ & I 886 & $33 \cdot 5$ & 3 & Board & $\mathrm{N}-47$ & I 620 & $29 \cdot 7$ & 3 & Board \\
\hline N-7 & I 884 & $29 \cdot 3$ & 3 & Board & $N-48$ & 1612 & 28.5 & 3 & Board \\
\hline N-8 & I 882 & $29 . \mathrm{I} \quad(2 \mathrm{I} .4)$ & $3(7)$ & Board (Pit) & $N-49$ & 1608 & 25.4 & 3 & Board \\
\hline N-9 & I 878 & 27.1 & 3 & Board & $\mathrm{N}-5^{\circ}$ & 1596 & 26.8 & 3 & Board \\
\hline N-10 & I 879 & 24.7 & 3 & Board & $N-5 \mathrm{I}$ & I 575 & 22.5 & 3 & Board \\
\hline$N-I I$ & I 877 & $24 \cdot 9$ & 3 & Board & $\mathrm{N}-5^{2}$ & I 555 & 22.3 & 3 & Board \\
\hline $\mathrm{N}-\mathrm{I} 2$ & 1878 & 22.3 & 3 & Board & N-53 & I 535 & 26. I & 3 & Board \\
\hline N-13 & 1878 & 23.8 & 3 & Board & N-54 & ${ }^{1} 5^{24}$ & 31.5 & 3 & Board \\
\hline $\mathrm{N}-14$ & 1878 & $23 \cdot 4$ & 3 & Board & $\mathrm{N}-55$ & 1512 & 20.5 & 3 & Board \\
\hline$N-15$ & 1876 & 22.5 & 3 & Board & $N-55^{\frac{1}{4}}$ & 1510 & $24 \cdot 3$ & 6 & Pit \\
\hline
\end{tabular}



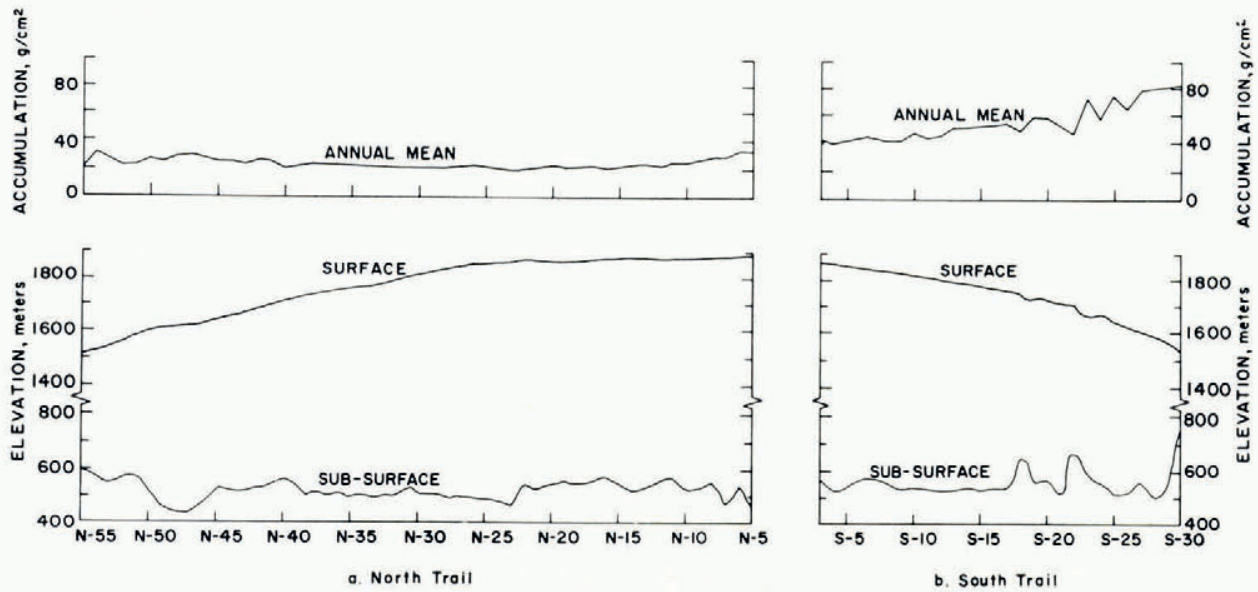

Fig. 2. Surface, subsurface and accumulation profiles along trails

\section{Regional Accumulation Trends}

In order to study regional accumulation trends, the aforementioned statistical methods were used. Rather than use geographical coordinates and elevation in the prediction model as in an earlier study (Mock, 1967), it was assumed that accumulation rates were a function of distance from a moisture source area and of elevation. It was further assumed that Melville Bugt, lying south of the Thule peninsula was the sole moisture source.

The initial model was a second-degree equation involving these two independent parameters:

$$
Y=a+b_{1} X_{1}+b_{2} X_{2}+b_{3} X_{1}^{2}+b_{4} X_{1} X_{2}+b_{5} X_{2}^{2}
$$

where $Y$ is the mean annual accumulation in $\mathrm{g} / \mathrm{cm}^{2}$ year, $X_{1}$ the elevation in meters, $X_{2}$ the distance from lat. $76^{\circ} \mathrm{N}$. in kilometers, and $a, b_{i}$ are regression constants.

The 76 th parallel was an arbitrarily chosen datum crossing Melville Bugt.

The results of this analysis are summarized in the equations shown in Table II. Equations (I) through (4) are based on all stake and board measurements made during this study. Equation (5) refers to stake data only from the south trail. Equation (6) is derived from all stake and board data plus accumulation data from Benson (1962) over a different portion of

Table II. Accumulation Prediction Equations in which $Y$ (Predicted Accumulation, g/cm ${ }^{2}$ year) is given as a Function of $X_{1}$ (Elevation, $m$ ) and $X_{2}$ (Distance from lat. $76^{\circ} \mathrm{N}$., $\mathrm{km}$ ), or $Y_{\mathrm{D}}$ (Deviation from Predicted $r$ ) as a Function of $X_{\text {id }}$ (Deviation from Regional Elevation, m) and $a$ (Surface Slope, deg)

\begin{tabular}{|c|c|c|c|c|c|}
\hline & Model & Equation & $\begin{array}{l}\text { Multiple } \\
\text { correlation } \\
\text { coefficient }\end{array}$ & $\begin{array}{l}\text { Standard } \\
\text { error of } \\
\text { estimate }\end{array}$ & \\
\hline & & & $R$ & $S$ & $F$ \\
\hline & (I) & $\begin{aligned} Y= & 215.1-1.3273445 X_{2}-3.698918 \times 10^{-5} X_{1}^{2}+ \\
& +4.9727393 \times 10^{-4} X_{1} X_{2}\end{aligned}$ & 0.975 & 3.62 & 398.5 \\
\hline & (2) & $Y=108.2+6.8356226 \times 10^{-2} X_{2}-3.2927104 \times 10^{-4} X_{1} X_{2}$ & $0.96 \mathrm{r}$ & $4 \cdot 43$ & $387 \cdot 3$ \\
\hline & (3) & $Y=108.5-2.9173618 \times 10^{-4} X_{1} X_{2} \quad \mathcal{N}=67$ & 0.960 & $4 \cdot 45$ & $765 \cdot 7$ \\
\hline & (4) & $Y=214.62\left(2.126 \times 10^{-5}\right)^{X_{1} X_{2}}$ & $0.97 \mathrm{I}$ & - & 1087.4 \\
\hline $\begin{array}{l}\text { South } \\
\text { trail only }\end{array}$ & $y^{(5)}$ & $\begin{aligned} Y= & -903.56+25.0467111 X_{2}+0.00014889504 X_{1}{ }^{2} \\
& -0.011631204 X_{1} X_{2}\end{aligned}$ & 0.975 & 2.78 & I 37.6 \\
\hline $\begin{array}{c}\text { Trails }+ \\
\text { Benson }\end{array}$ & (6) & $\begin{aligned} Y= & 24 \mathrm{I} .2-3.5600362 X_{2}+6.4055777 \times 10^{-5} X_{1}{ }^{2} \\
& -\mathrm{I} .1300603 \times \mathrm{IO}^{-3} X_{1} X_{2}+\mathrm{I} .8144079 \times \mathrm{IO}^{-2} X_{2}{ }^{2} \\
& n=77 \quad D F=7^{2}\end{aligned}$ & 0.953 & $4.8 \mathrm{I}$ & I 77.9 \\
\hline & (7) & $Y_{\mathrm{D}}=2.4-0.8211 X_{1 \mathrm{D}}-259 \cdot 106 \sin a$ & 0.866 & 2.63 & 31.5 \\
\hline
\end{tabular}


the Thule peninsula. Equation (7) is based on an analysis of residuals from Equation (I) and will be discussed in detail in a later section.

Equations ( 1 ) through (3) are all derived from the original model and the same data by a deletion process, the objective being to reach a reasonable compromise between the statistical measures of fit and the size of the predictor equation. Equation (4) is included simply to indicate that the parameters distance and elevation can be used successfully in an exponential as well as a polynomial model. Figure 3 shows measured accumulation and predicted accumulation from Equation ( $\mathrm{I}$ ) plotted versus distance.

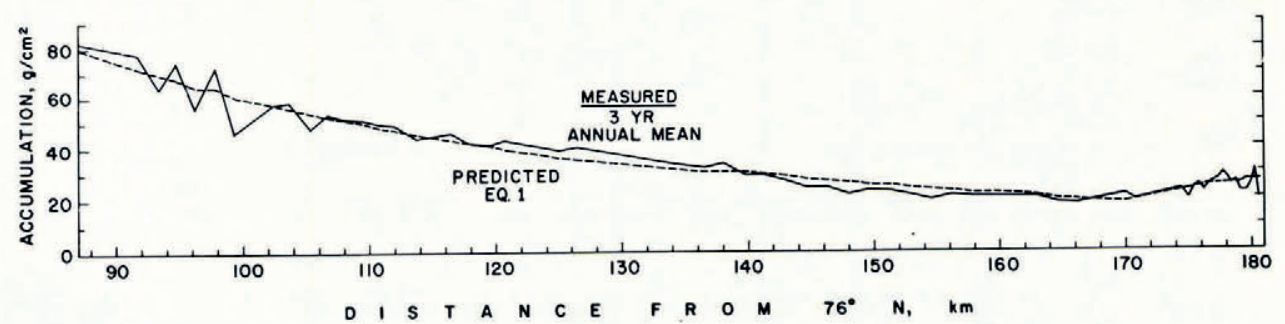

Fig. 3. Measured and predicted mean annual accumulation plotted versus distance from moisture source

Before proceeding further the question of how closely the three years of accumulation data used in this analysis approximate the true mean annual accumulation needs examination. This problem, in turn, can be subdivided into two problems:

(a) What is the temporal variability?

(b) What is the spatial variability (within a few meters)?

Lister (I96r) in a study conducted at Northice, approximately $500 \mathrm{~km}$ east of the present study area found that within an area $30 \mathrm{~m}$ square the annual accumulation could vary by I 00 per cent and deviate $5^{0}$ per cent from the mean of $14.9 \mathrm{~g} / \mathrm{cm}^{2}$. Assuming this represents normal variability given the wind conditions prevailing at Northice then we can use the numerical value of $\pm 7 \mathrm{~g} / \mathrm{cm}^{2}$ as a measure of possible error in a single measurement assuming wind conditions to be similar to those at Northice. The fact that the profiles of each year shown in Figure 4 are closely similar indicates that deviations are nearly constant with time at each station. If this is the case then temporal variability is indicated by the standard deviations at each station. Still the problem of the validity of the means from three years' data is unanswered.

Examining Table I again shows that with a single exception, station $\mathrm{S}-55^{-1} / 4$, all accumulation rates determined from pits are substantially lower than the values recorded by stake or board measurements at the same or adjacent sites. This suggests that the three-year accumulation totals may represent an anomalously high period.

Another method of gaining at least a qualitative idea of the validity of the accumulation rate measurements is to look at regression curves for I, 2, 3 and 4 years of data respectively. Assuming that the model used would provide a perfect fit if the true mean values were available, the curves using means based on successively greater numbers of years of data should show increasingly better fits. Such is the case as shown in Figure 5 where the model used in Equation (5) of Table II was processed using successively $\mathrm{I}, 2,3$ and 4 year means of accumulation from the trail south of Camp Century. Each of the 3 statistics shown, $R, F$ and $S$ indicate greater success of the model with each increase in the sample size used to determine mean values.

Figure 7 shows isohyets as a function of distance and elevation based on Equations ( $\mathrm{I}$ ) and (6) respectively. The different form shown by the two groups of isohyets is indicative of the limitations of this type of analysis. The data used to arrive at Equation (I) can be con- 


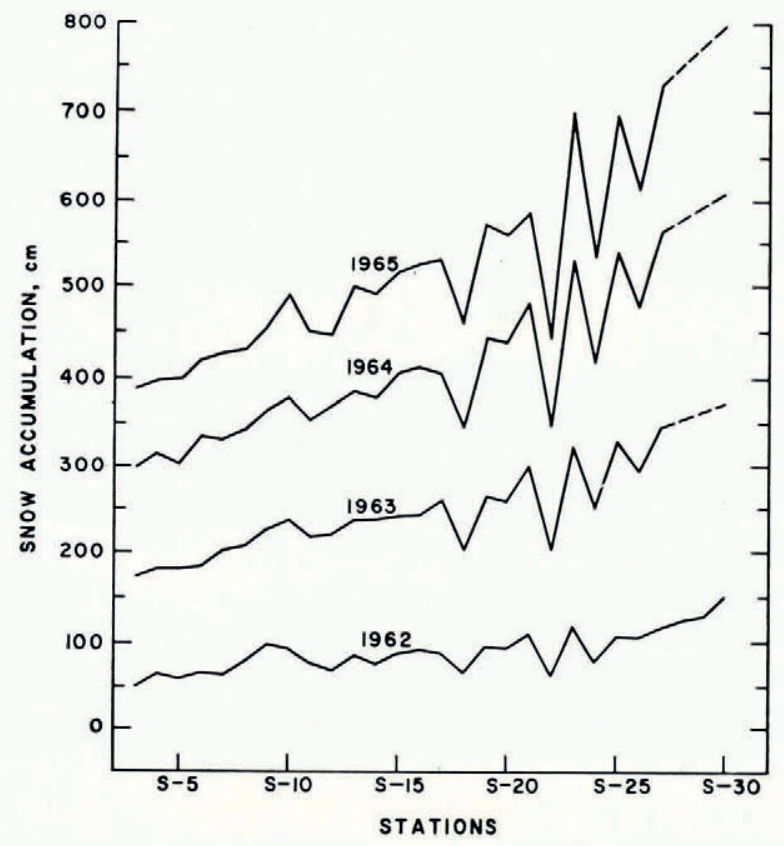

Fig. 4. Total accumulation on south trail, $1961-6_{5}$

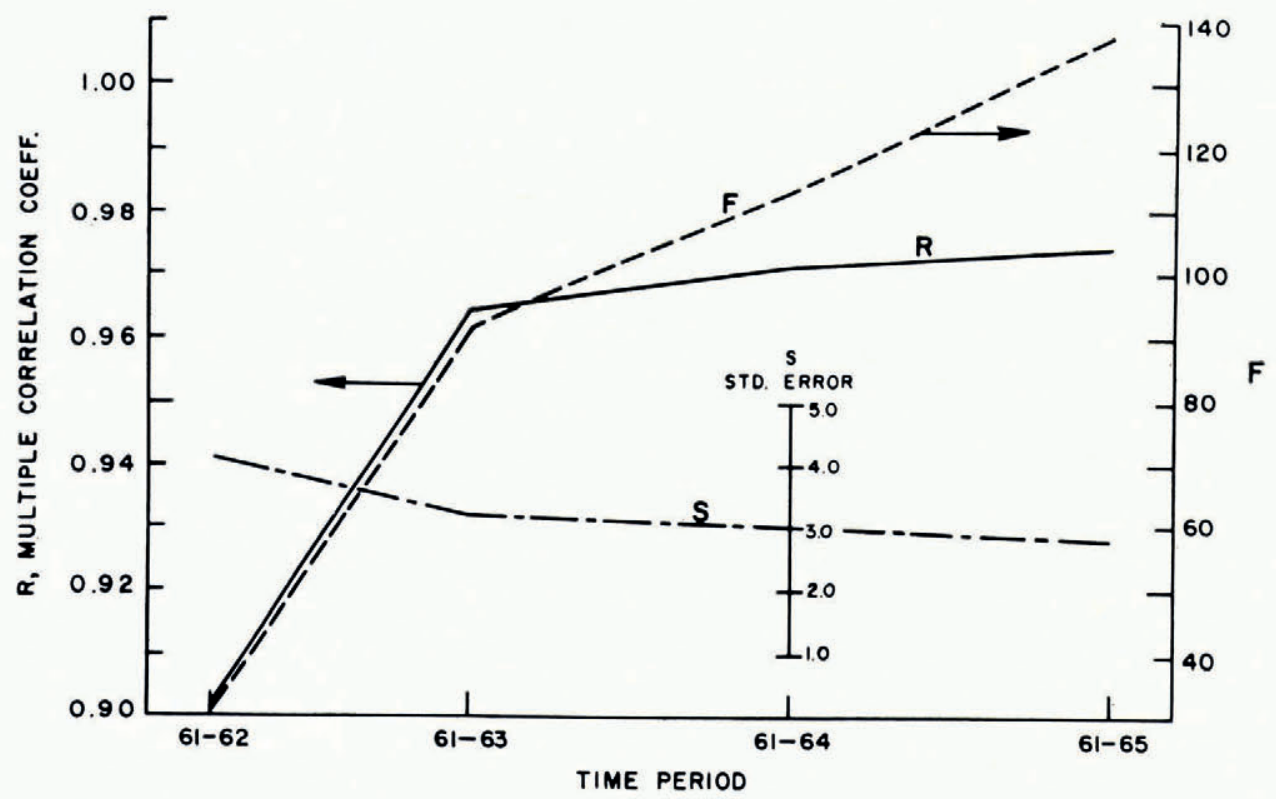

Fig. 5. Statistical data for south trail data 


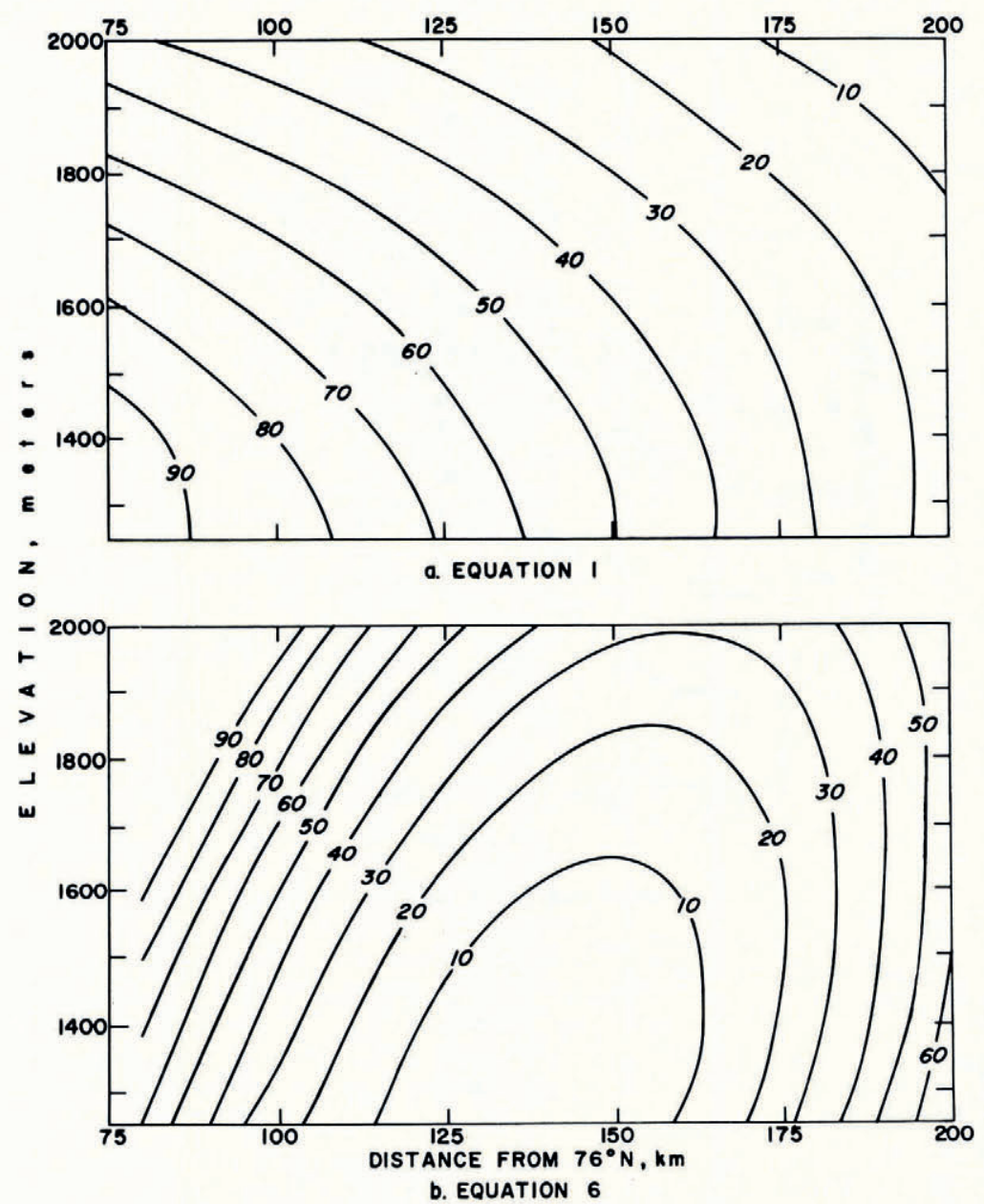

Fig. 6. Isohyets plotted versus elevation and distance from moisture source

sidered a subset of the data used to determine Equation (6). The entire body of data used in this analysis is itself only a subset of the total population, and the inherent danger of error must be borne in mind when extrapolating beyond the range of the data set, which we now proceed to do.

In Figure 7 the results of the regional analysis have been summarized in an isohyetal map of the Thule peninsula. The position of the isohyets were determined from Equation (6) using Figure 6. In terms of precipitation regimes existing over highlands in low and mid latitudes, the pattern shown in Figure 7 appears anomalous. Ideally when an air mass approaches an elevation barrier, the lifting effect causes condensation and a resulting increase in precipitation up to some level where the absolute moisture content is diminished to such an extent that precipitation diminishes. When the elevation barrier is breached and subsidence of the air begins, precipitation rapidly diminishes as adiabatic warming brings air mass temperatures above the dew point. The actual distribution of precipitation will depend upon many factors such as absolute height of the barrier, steepness of slope and many meteorological variables. Benson ( 1962 ) pointed out many of the difficulties in observing the precipita- 


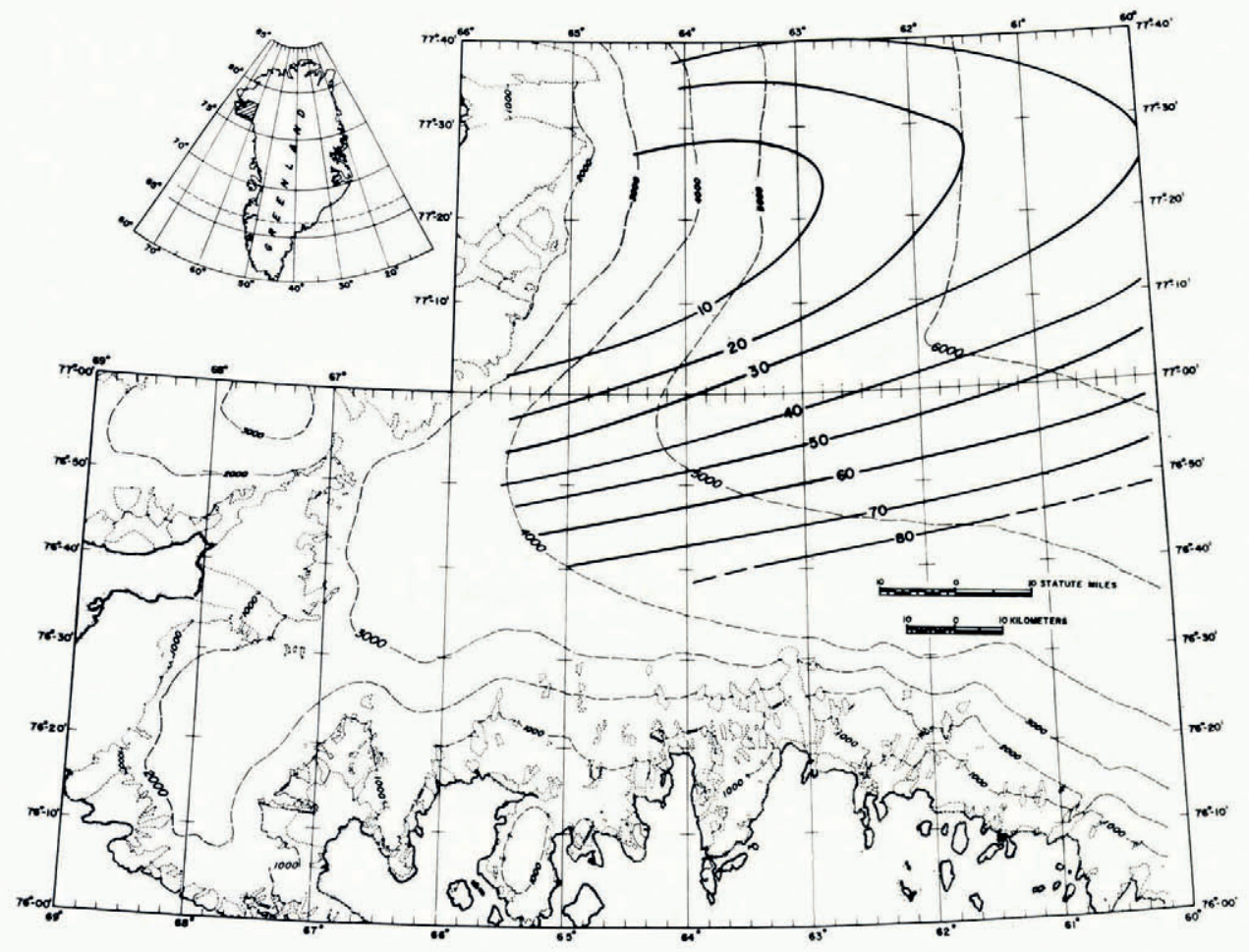

Fig. 7. Isohyetal map of the Thule peninsula

tion patterns over mountain barriers and observed that the Thule peninsula in many respects, represented a simplified model on which to observe such patterns.

The pattern shown in Figure 7 differs from the ideal model in two respects: there appears to be no zone in which accumulation increases with elevation and there is no abrupt change in accumulation on crossing the crest. Examination of Figure $6 \mathrm{~b}$ indicates that there would actually be an increase in accumulation with elevation if surface slopes were great enough. As it is, the decrease in accumulation with distance completely masks the effect of elevation including the development of any noticeable discontinuity near the crest. It is probable that along the Melville Bugt coast, in the mountainous region and on the ice sheet for some indeterminate distance inland, a rapid increase in accumulation or precipitation rates does in fact occur. Once this region is passed the very gentle surface slopes existing on the ice sheet preclude noticeable orographic effects upon accumulation.

In terms of the preceding arguments the increase in accumulation northwards from lat. $77^{\circ} 20^{\prime} \mathrm{N}$. becomes difficult to explain. In order of relative probabilities the most likely causes are:

I. The model is breaking down.

2. The influence of a secondary moisture source is becoming dominant.

3. Increased katabatic flow funneling into this area causes warmer air masses to be lifted giving increased accumulation.

\section{Local Accumulation Patterns}

Figures 2 and 4 show the large variations in accumulation rates occurring within limited distances, particularly from mile S-I 5 to S-30 on the south trail. Figure 4 illustrates the 
persistence of these variations while Figure 2 indicates their relationship to surface relief features. Detail is not sufficiently defined to state categorically that maximum accumulation rates occur in lowest parts of the hollows, but it can be seen that high and low accumulation rates are associated with topographic lows and highs respectively.

Equations (I) through (4) can each be used to calculate the predicted accumulation $\Upsilon_{\mathrm{p}}$ at each station. The residual $\Upsilon_{\mathrm{D}}$ can be calculated from the observed accumulation $\left(\Upsilon_{\mathrm{o}}\right)$ as

$$
r_{\mathrm{D}}=r_{\mathrm{o}}-\Upsilon_{\mathrm{p}}
$$

Since $R_{\mathrm{s}}$ represents deviations of the predicted from observed accumulation rates, it is a measure both of errors and of deviations caused by factors unaccounted for in the original model. Of these factors the effect of local topography superimposed upon the regional slope becomes quite evident on examination of Figure 2. From station S-1 5 to S-3o a series of steps break the generally smooth slope of the ice sheet. Coincident with the increasing size of surface topographic features, accumulation rates oscillate much more widely around the curve of predicted accumulation.

Qualitatively it can be seen from Figure 2 that high accumulation rates are associated with topographic lows and vice versa. The spacing of accumulation stakes is insufficient to show the fine detail over any single wave or step so it becomes necessary to use statistical methods to determine the local patterns. A method similar to that used by Black and Budd (1964) was resorted to, the model being

$$
\Upsilon_{\mathrm{D}}=a+b_{\mathrm{I}} X_{\mathrm{ID}}+b_{2} \sin \alpha
$$

where $X_{\mathrm{ID}}=\left(X_{\mathrm{IO}}\right)_{n}-\frac{1}{4}\left\{\left(X_{\mathrm{IO}}\right)_{n-\mathrm{I}}+2\left(X_{\mathrm{IO}}\right)_{n}+\left(X_{\mathrm{IO}}\right)_{n+1}\right\},\left(X_{\mathrm{IO}}\right)_{n}$ being the observed elevation at station $n$, and $\alpha$ the surface slope at station $n$. The result is shown as Equation (7) of Table II. Using Equations ( I) and (7) the accumulation profile over a complete surface wave can be calculated. This has been done for a prominent step on the south trail; the result is shown in Figure 8. Over this particular feature, the absolute maximum accumulation occurs at the low point of the depression while minimum accumulation occurs near the crest of the rise. Figure 8 also shows the surface and subsurface profiles over the trail section. The step-like nature of the topography is quite evident, as is the fact that, when superimposed on the regional profile, the feature is shown to be a wave.

\section{Origin of Wave Features}

Undulating and step features have been observed in Greenland (Bader, I96I; Bourgoin, 1956) and Antarctica (Swithinbank, I959; Black and Budd, I964; Gow and Rowland, I966) both near the coasts and in the interiors. Recent discussions have centered on the origin of these features; whether they are the result of accumulation variations or are a phenomenon associated with bed topography and flow.

Nye ( 1959) has shown that perturbations of the equilibrium profile for central Antarctica would disappear quite rapidly (0.005 to 1o years for features of wavelength 3 to $140 \mathrm{~km}$ ) and concludes that observed features must represent an equilibrium profile reflecting the subsurface topography.

Black and Budd ( 1964 ) observed accumulation patterns over waves which would tend to cause them to migrate upslope. If indeed a wave does migrate upslope it then becomes a perturbation of the equilibrium profile and should dissipate with the time constants calculated by Weertman (1958). However, at the same time it causes a perturbation in the accumulation profile which may tend to perpetuate, cause continued migration, or obliterate the waves. Waves which have been observed in the interior of Antarctica (Gow and Rowland, i966) appear unrelated to bed topography and, as postulated by Gow, may have migrated into their present position by the mechanism proposed by Black and Budd.

The waves observed in the present study are unquestionably a result of bed topography, as each surface feature is directly associated with an observable feature on the bed, as is 

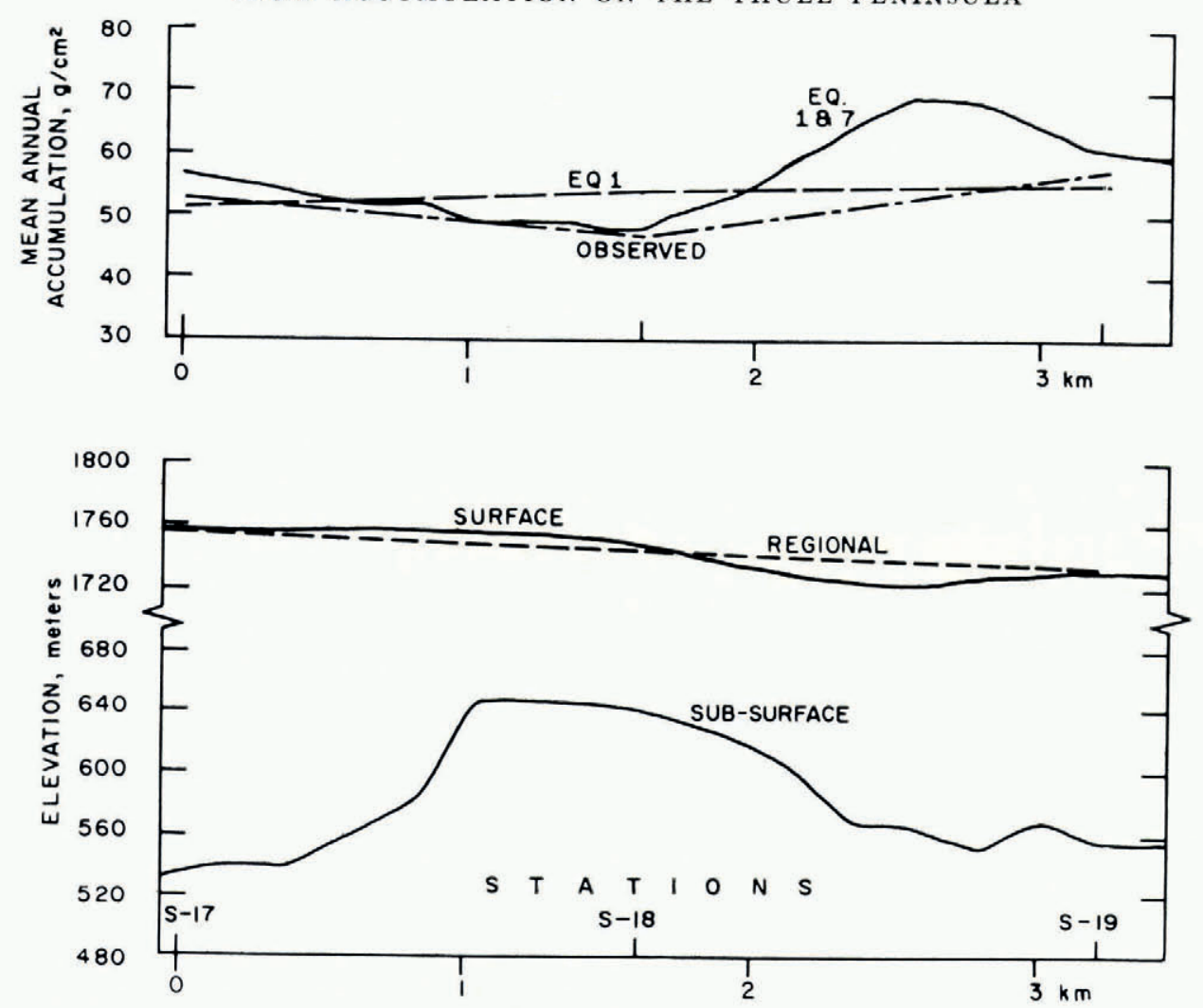

Fig. 8. Accumulation, surface and subsurface profiles over wave feature

readily evident in Figure 2. Although there has been some success in quantitatively correlating surface profiles with bed topography (Bourgoin, I956; Robin, 1958) more recent work (Robinson, 1966) has yielded, at best, only qualitative results.

Nye (1959) has shown that the change in surface slope caused by a subsurface feature is given approximately by

$$
\frac{\Delta \alpha}{\alpha} \approx \frac{m+\mathrm{I}}{m} \cdot \frac{P}{h} \approx \mathrm{I} \cdot 4 \frac{P}{h}
$$

where $\Delta \alpha$ is the slope change, $\alpha$ the regional slope, $h$ the regional ice thickness, $P$ the height of the subsurface feature, and $m$ a constant assumed to be 2.5 .

Using this expression to calculate the bottom profile from the observed surface slopes gives the profiles shown in Figure 9. The predicted profile departs quite radically from the observed, to such an extent as to be worthless. This is not surprising considering that several of the assumptions made by Nye in his derivation are violated by the physical problem represented here. It is of interest to examine these assumptions and, if possible, recalculate profiles without them. Nye assumed that

and that

$$
\Delta \alpha \ll \alpha
$$

$$
\Delta h \ll h
$$

where $\Delta h$ is the change in thickness over an obstacle and $h$ is the regional ice thickness. Inequality (I I) does not hold in the profile shown in Figure 8 where in fact $\Delta \alpha>\alpha$. The bed profile can be calculated without assuming Inequalities (I I) and (I2) from the expression: 


$$
P=h\left(\frac{\alpha_{0}}{\alpha_{0}+\Delta \alpha}\right)^{m / m+1}-h+\epsilon
$$

where $P$ is the height of the obstacle and $\epsilon$ the deviation from regional elevation. The profile calculated from Equation ( 13 ) is shown in Figure 9 along with the profile calculated from Equation (10). It is difficult to decide which is more satisfactory, both being so far from the actual profile.

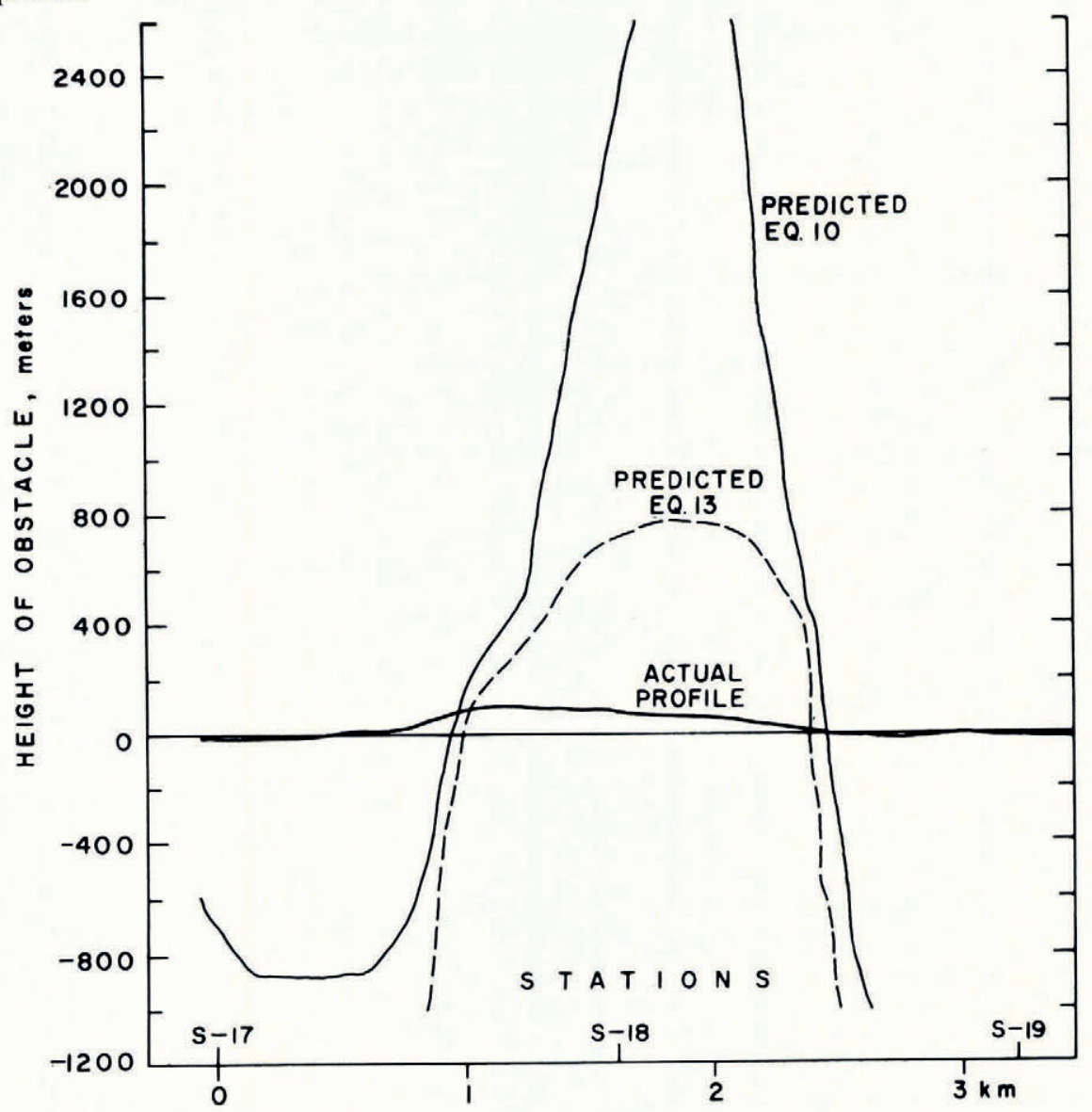

Fig. 9. Observed and predicted subsurface profiles at wave feature

Nye also assumed the following relationship between sliding velocity $u$ and shear stress $\tau$ at the bed.

$$
u=\left(\frac{\tau}{A}\right)^{m}
$$

where $A$ is independent of stress but depends on temperature and $m$ is a constant. For purposes of the derivation and in the absence of any other information, $A$ has been assumed constant, but in fact, where the height of bed features is a significant fraction of the thickness of the ice sheet (9 per cent in this case), it will probably change significantly in the region of the bed features. Unfortunately the changes which might be expected in $A$, its magnitude decreasing with the higher bed temperatures over a feature, would only accentuate the already erroneous profile. 
Present theory seems inadequate to account for the observed profiles, under the assumption that the presence of a single obstacle causes none or only negligible effects on the mass flux both upstream and downstream of the obstacle, i.e. that the mass flux of the real ice sheet $q$ is equal to $q_{0}$ the mass flux of a reference ice sheet with no obstacle. If the ice sheet is in a non-equilibrium condition and is adjusting to changed conditions, then conceivably $q \neq q_{\mathrm{o}}$ and the observed profile represents a transient state.

\section{Camp Century station glaciology}

Regression methods similar to those previously described, were used to analyze the measured accumulation data from the level net. Coordinates on an arbitrarily established grid were used to calculate accumulation contours. Cubic, quadratic and simple linear models were tested, and the linear model gave a sufficiently good fit $(R=0.884)$ to be used for further work. Trend surfaces of accumulation are shown in Figure Io and show a substantial gradient existing across the $27 \mathrm{~km}^{2}$ area from more than $37 \mathrm{~g} / \mathrm{cm}^{2}$ in the south-east to less than $29 \mathrm{~g} / \mathrm{cm}^{2}$ in the north-west. Since most studies, e.g. drilling and deep pit studies, have been concentrated on the south-east side of the camp, we will consider $35 \mathrm{~g} / \mathrm{cm}^{2}$ as the mean annual accumulation at Camp Century. Accumulation determinations from this study as well as all other measurements made at Camp Century are summarized in Table III.

Time interval

$1964-47$
$1964-47$
$1962-55$
$1964-1800$
$1965-1876$
$1966-63$

Table iII. Camp Century Accumulation

\begin{tabular}{ll}
\multicolumn{1}{c}{ Method } & $\begin{array}{r}\text { Accumulation rate } \\
\mathrm{g} / \mathrm{cm}^{2} \text { year }\end{array}$ \\
Firn stratigraphy & 31.2 \\
Fission products & $3^{1.2}$ \\
Firn stratigraphy & $31.8 \pm 5 \cdot 7$ \\
210Pb & $32 \pm 3$ \\
Firn stratigraphy & 36.7 \\
Trend surface & 35
\end{tabular}

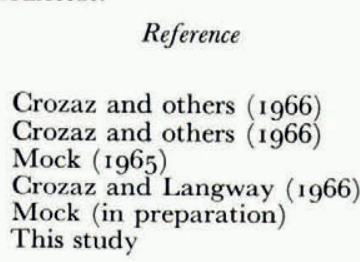

Reference

Crozaz and others (1966)

Crozaz and others (1966)

Mock (1965)

Crozaz and Langway (1966)

Mock (in preparation)

This study

Topographic maps were compiled for each of the three years in which spirit leveling was done, I963, I964 and I966, in order to study any surficial features which might be present. Previous work by Benson (I959) in an area $130 \mathrm{~km}$ to the east has shown a surprisingly large amount of "topography" in an area visually undistinguished. The 1963 and r 964 surveys showed no unusual features or changes in the surface. The r 966 survey, however, revealed the development of a distinct feature in the vicinity of stations 24 and 25 , a broad indentation of the contours. In Figure Io both the 1964 and I 966 surface contours are shown in this region.

The development of such a feature would, at first thought, be the result of decreased accumulation in the affected area, probably as a result of wind scouring, initiated perhaps by some minor transient feature. The prevailing wind directions as shown in the wind rose in Figure ro would lend credence to such a view.

A cursory inspection of the accumulation data reveals that accumulation rates are highest at the point where the surface has shown the maximum relative lowering. This is shown in the profiles of Figure I I. It appears that the development of the slight surface depression rather than being the result of accumulation deficiencies has, in fact, caused an increase in accumulation rates.

A topographic map of the subsurface at Camp Century has been constructed from the available radar sounding data. The map, shown as Figure 12 is considered to be the best logical fit of the several interpretations possible from the data. Using Figures ro and 12, an ice thickness of $\mathrm{I} 370 \mathrm{~m}$ is predicted at the Camp Century deep bore-hole site. Recently the ice sheet was completely bored through and the sub-ice material reached at a depth of I $387.4 \mathrm{~m}$ (Hansen and Langway, I966), a difference of only I.5 per cent from the depth predicted here.

If the I 966 profile of Figure i I represents the equilibrium profile then Equation (i 3 ) can be used to calculate the height of the subsurface feature causing the observed change in slope. 


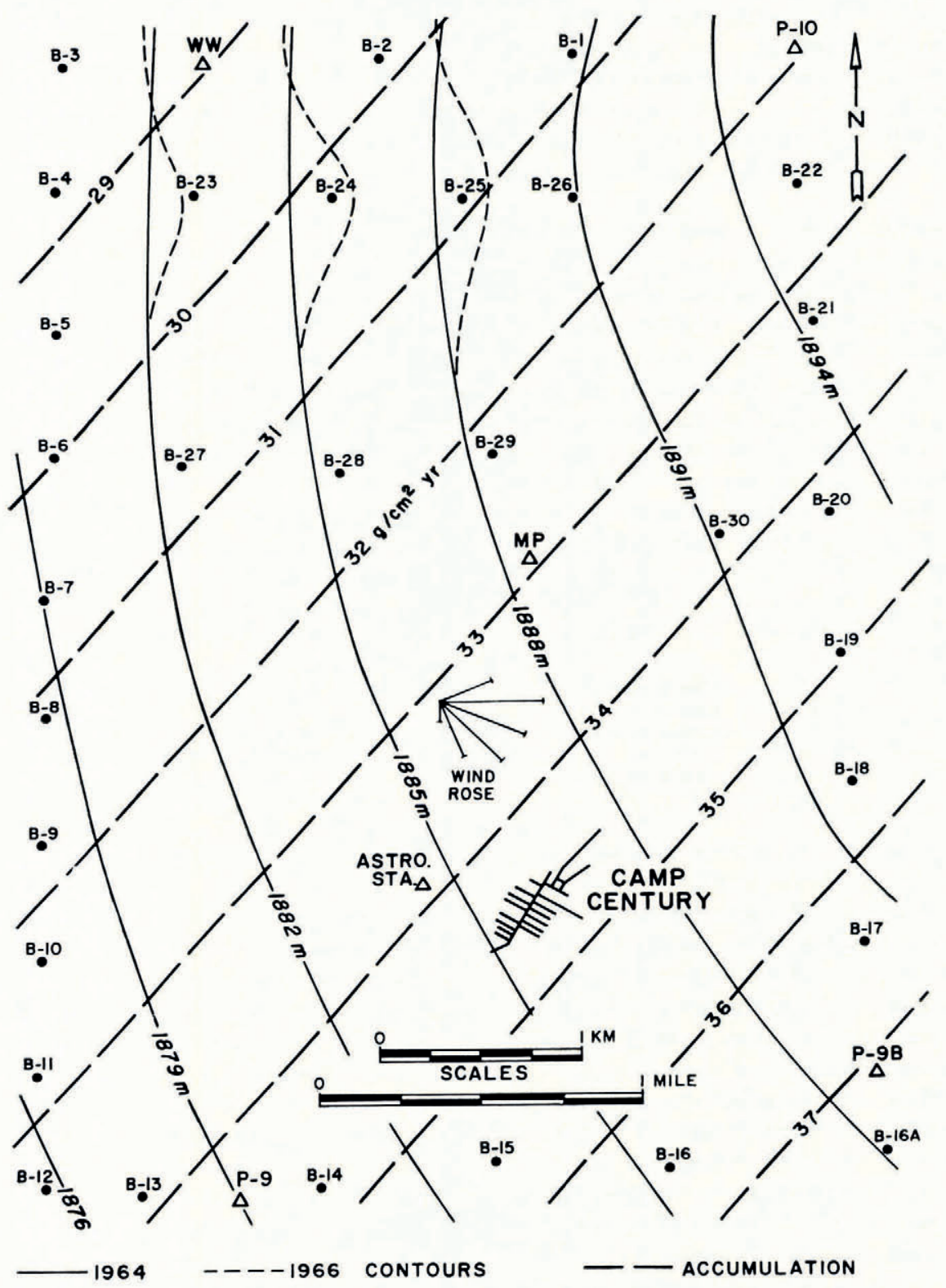

Fig. 1o. Topographic and accumulation trend surface map, Camp Century area

The result predicts a hill $\mathrm{I}_{5} \mathrm{~m}$ in height and a similar calculation using Equation (Io) predicts one of $244 \mathrm{~m}$. It seems reasonably safe to assume that the surface feature does represent a perturbation from the equilibrium profile. Weertman's analysis (1958) of perturbations from an equilibrium ice thickness enables a calculation of the characteristic decay time $t$, necessary for a small departure $\Delta h$, from the equilibrium ice thickness $h$, to decay to a small value. The expression is 

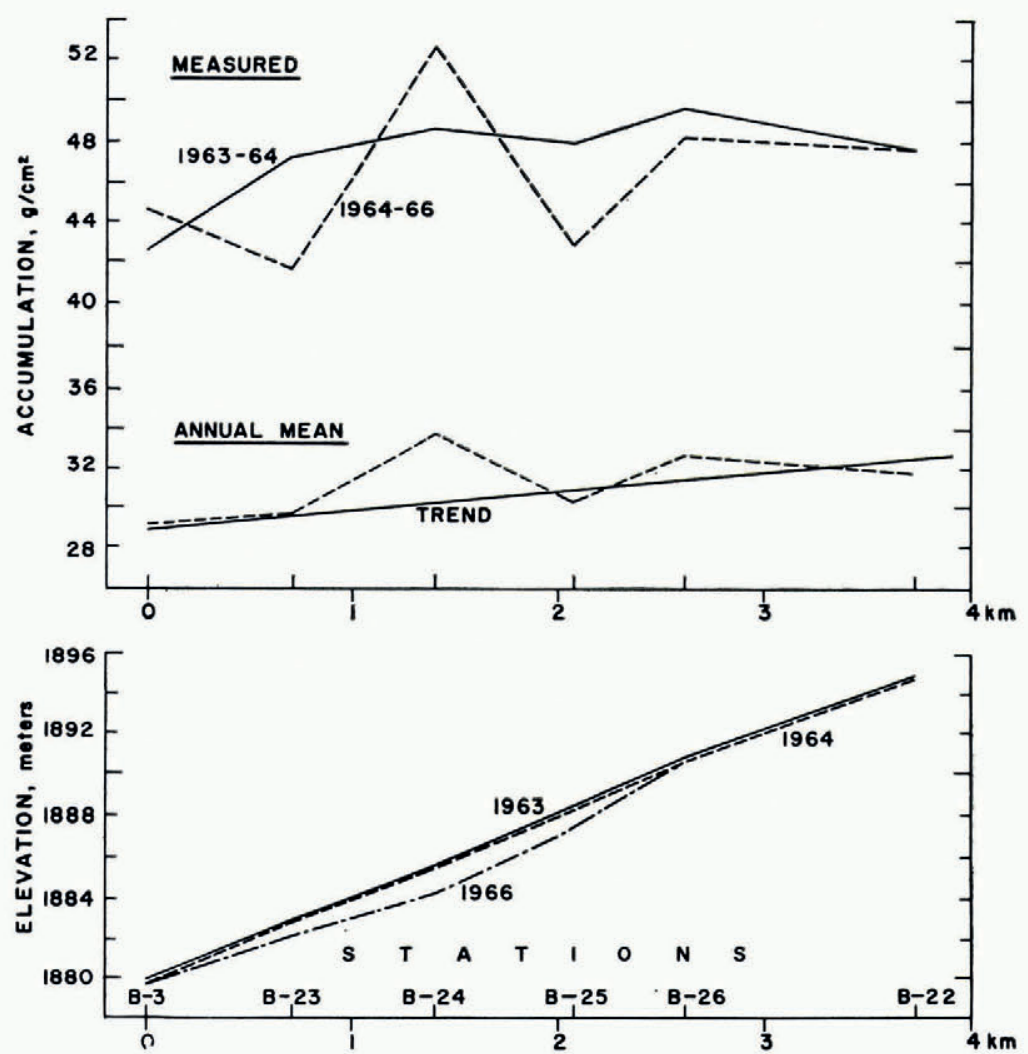

Fig. II. Accumulation and surface profiles over valley feature at Camp Century

$$
t=\left(B+\frac{4 \pi^{2} D}{\lambda^{2}}\right)^{-1}
$$

where $B=(m+\mathrm{I})(Q u+a) / h, Q=\alpha-\beta, \alpha$ is the surface slope, $\beta$ the bed slope, $u$ the velocity, $a$ the accumulation rate, $D=m u H / \alpha$, and $\lambda$ the wavelength of the perturbation. For this feature $t$ is equal to $0.006 \mathrm{~d}$ or approximately $9 \mathrm{~min}$. Since it took substantially longer than this to carry the spirit level lines over the feature, it is likely that this figure is incorrect. What does appear evident is that this feature is not the result of wind action or differential accumulation and is inexplicable in terms of existing flow theory both in terms of origin and maintenance.

\section{Summary and Conclusions}

Regression analysis enables satisfactory regional predictions of mean annual accumulation to be made from the parameters distance from moisture source and elevation. The regional pattern developed from this model is consistent with observed results and explicable for the most part in terms of general meteorological principles. Mean annual accumulation is greater than $80 \mathrm{~g} / \mathrm{cm}^{2}$ on the southern slope of the peninsula but decreases rapidly with increasing distance from Melville Bugt and increasing elevation to less than $20 \mathrm{~g} / \mathrm{cm}^{2}$.

Large deviations, up to $15 \mathrm{~g} / \mathrm{cm}^{2}$, from regionally predicted accumulation values are associated with localized topographic features, in particular a series of waves or steps. Detailed accumulation profiles over these features can be predicted from an analysis of deviations from 


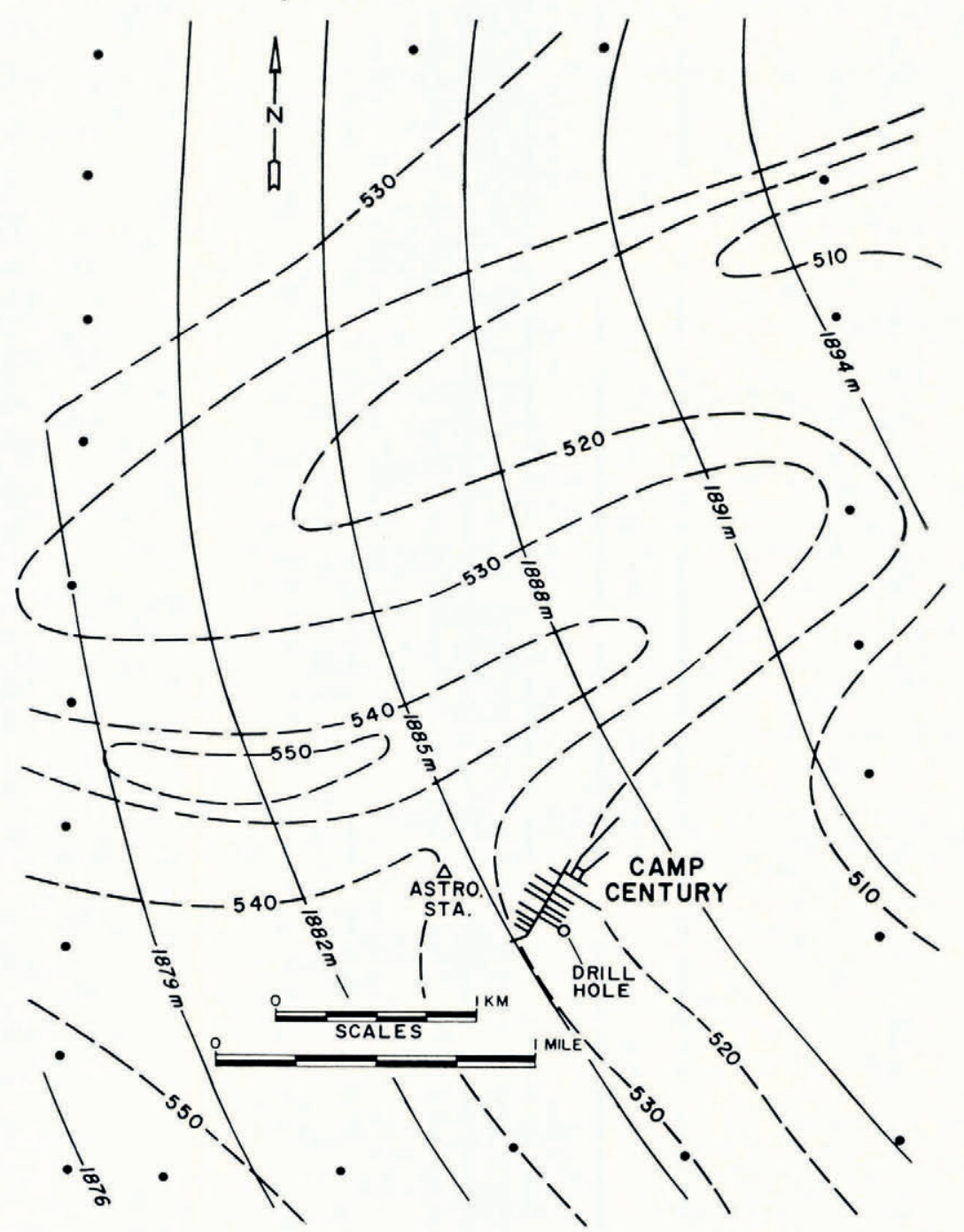

Fig. 12. Subsurface topographic map at Camp Century

regionally predicted accumulation, deviations from regional elevation, and surface slope. Such analysis reveals highest accumulation rates associated with the topographically lowest parts of the features and vice versa. Qualitatively, these features are associated with bed topography, as shown by surface and subsurface profiles, but they cannot be quantitatively accounted for by existing flow theory because of boundary condition violations.

Contour maps showing surface elevation, subsurface elevation, and mean annual accumulation were constructed for a limited area of $27 \mathrm{~km}^{2}$ surrounding Camp Century. Mean annual accumulation shows a systematic decrease from greater than $37 \mathrm{~g} / \mathrm{cm}^{2}$ in the south-east to less than $29 \mathrm{~g} / \mathrm{cm}^{2}$ in the north-west. At the camp itself a mean annual accumulation of $35 \mathrm{~g} / \mathrm{cm}^{2}$ is indicated. The contour maps of elevation have revealed the development of a small change in surface shape, best described as a valley-like feature with a relative surface lowering of over $\mathrm{I} \mathrm{m}$ causing accumulation rates to increase within the area of the surface lowering. 
Bed topography provides no clue to the cause of the feature which appears to be a flow phenomenon.

\section{Acknowledgements}

It is a pleasure to acknowledge the able assistance both in the field and laboratory during various phases of this project of Professor Hernan O. Pallardo, Mr. T. C. Davis, Jr., Mr. Donald Alford, Mr. Robert Bucher and SP/4 Roger Doescher. Without the capable logistic support provided by the officers and men of the U.S. Army Research Support Group, this work could not have been accomplished. Critical reviews by Dr. C. C. Langway, Dr. W. F. Weeks, Mr. J. A. Bender, Mr. A. J. Gow and Mr. C. F. Keeler are kindly appreciated.

\section{MS received 14 Fuly 1967}

\section{REFERENCES}

Bader, H. 196I. The Greenland ice sheet. U.S. Cold Regions Research and Engineering Laboratory. Cold regions science and engineering. Hanover, N.H., Pt. I, Sect. $\mathrm{B}_{2}$.

Bader, H., and others. 1955. Excavations and installations at SIPRE test site, Site 2, Greenland, by H. Bader, R. W. Waterhouse, J. K. Landauer, B. L. Hansen, J. A. Bender and T. R. Butkovich. U.S. Snow, Ice and Permafrost Research Establishment. Report 20.

Bailey, J. T., and others. 1964. Radio echo sounding of Polar ice sheets, by J. T. Bailey, S. Evans and G. de Q. Robin. Nature, Vol. 204, No. 4957, p. 420-2 I.

Benson, C. S. 1959. Physical investigations on the snow and firn of northwest Greenland 1952, I953 and 1954. U.S. Snow, Ice and Permafrost Research Establishment. Research Report 26.

Benson, C. S. 1962. Stratigraphic studies in the snow and firn of the Greenland ice sheet. U.S. Snow, Ice and Permafrost Research Establishment. Research Report 70.

Black, H. P., and Budd, W. 1964. Accumulation in the region of Wilkes, Wilkes Land, Antarctica. Journal of Glaciology, Vol. 5, No. 37, p. 3-15.

Bourgoin, J.-P. 1956. Quelques caractères analytiques de la surface et du socle de l'inlandsis groenlandais. Annales de Géophysique, Tom. 12, No. I, p. 75-83.

Bull, C. 1958. Snow accumulation in North Greenland. Journal of Glaciology, Vol. 3, No. 24, p. $237-48$.

Clarke, G. K. C. 1966. Seismic survey northwest Greenland, 1964. U.S. Cold Regions Research and Engineering Laboratory. Research Report 191 .

Crozaz, G., and Langway, C. C., jr. 1966. Dating Greenland firn-ice cores with Pb-2 1o. Earth and Planetary Science Letters, Vol. 1 , No. 4, p. 194-96.

Crozaz, G., and others. 1966. Artificial radioactivity reference horizons in Greenland firn, by G. Crozaz, C. C. Langway, Jr., and E. Picciotto. Earth and Planetary Science Letters, Vol. 1, No. 1, p. $42-48$.

Goldthwait, R. P. 1960. Study of an ice cliff in Nunatarssuaq, Greenland. U.S. Snow, Ice and Permafrost Research Establishment. Technical Report 39 .

Gow, A. J., and Rowland, R. I965. On the relationship of snow accumulation to surface topography at "Byrd station", Antarctica. Journal of Glaciology, Vol. 5, No. 42, p. 843-47.

Griffiths, T. M. 1960. Glaciological investigations in the TUTO area of Greenland. U.S. Snow, Ice and Permafrost Research Establishment. Technical Report 47.

Hansen, B. L., and Langway, C. C., jr. 1966. Deep core drilling in ice and core analysis at Camp Century, Greenland, 1961-1966. Antarctic fournal of the U.S., Vol. 1, No. 5, p. 207-08.

Krumbein, W. C., and Graybill, F. A. [1966.] An introduction to statistical models in geology. New York, McGraw-Hill.

Langway, C. C., jr. I961. Accumulation and temperature on the inland ice of North Greenland, 1959. Fournal of Glaciology, Vol. 3, No. 3o, p. Io I 7-44.

Lister, H. 196r. Accumulation and firnification in North Greenland. Folia Geographica Danica, Tom. 9, p. I63-74.

Mock, S. J. 1963. Tellurometer traverse for a surface movement survey in N. Greenland. Union Géodésique et Géophysique Internationale. Association Internationale d'Hydrologie Scientifique. Assemblée générale de Berkeley, 19-831-8 1963. Commission des Neiges et des Glaces, p. 147-53.

Mock, S. J. 1965. Glaciological studies in the vicinity of Camp Century, Greenland. U.S. Cold Regions Research and Engineering Laboratory. Research Report 157.

Mock, S. J. 1967. Accumulation patterns on the Greenland ice sheet. U.S. Cold Regions Research and Engineering Laboratory. Research Report 233.

Mock, S. J., and Weeks, W. F. I966. The distribution of ro meter snow temperatures on the Greenland ice sheet. Fournal of Glaciology, Vol. 6, No. 43, p. 23-41.

Nobles, L. H. 1960. Glaciological investigations, Nunatarssuaq ice ramp, northwestern Greenland. U.S. Snow, Ice and Permafrost Research Establishment. Technical Report 66.

Nye, J. F. 1959. The motion of ice sheets and glaciers. Fournal of Glaciology, Vol. 3, No. 26, p. $493^{-507 .}$

Rinker, J. N., and Mock, S. J. 1967. Radar ice thickness profiles, northwest Greenland. U.S. Cold Regions Research and Engineering Laboratory. Special Report $8 \mathrm{1}$. 
Robin, G. de Q. 1958. Glaciology. III. Seismic shootings and related investigations. Norwegian-British-Swedish Antarctic Expedition, 1949-52. Scientific Results, Vol. 5.

Robinson, E. S. 1966. On the relationship of ice-surface topography to bed topography on the South Polar plateau. Journal of Glaciology, Vol. 6, No. 43, p. 43-54.

Schytt, V. 1955. Glaciological investigations in the Thule Ramp area. U.S. Snow, Ice and Permafrost Research Establishment. Report 28.

Swithinbank, C. W. M. 1959. Glaciology. I. The morphology of the inland ice sheet and nunatak areas of western Dronning Maud Land. Norwegian-British-Swedish Antarctic Expedition, 1949-52. Scientific Results, Vol. 3, D, p. 97-117.

Waite, A. H., jr. 1966. International experiments in glacier sounding, I963 and 1964. Canadian Journal of Earth Sciences, Vol. 3, No. 6, p. 887-92.

Weertman, J. 1958. Traveling waves on glaciers. Union Géodésique et Géophysique Internationale. Association Internationale d'Hydrologie Scientifique. Symposium de Chamonix, $16-24$ sept. 1958, p. 162-68. 